\title{
ALTERNATE METHODS FOR THE ARTIFICIAL RELEASE OF SNOW AVALANCHES
}

\author{
By Edward R. LaChapelle \\ (Geophysics Program and Department of Atmospheric Sciences, University of Washington, \\ Seattle, Washington 98195, U.S.A.)
}

\begin{abstract}
A series of devices have been developed and tested which are designed to initiate the release of snow avalanches by mechanically disturbing or altering the snow cover. These serve as substitutes for the conventional use of high explosive; and artillery projectiles. Canisters charged with an explosive mixture of gases can be fired electrically by remote control and recycled to fire again as needed. Air bags placed underneath the snow cover can be inflated with reasonably low pressure to disrupt and dislodge the snow cover. Energetic vibrators powered by compressed air can dislodge unstable snow under favorable circumstances. A polyethylene membrane placed on the ground surface of a steep mountainside effectively inhibits the accumulation of snow by allowing new snow to slide off as fast as it accumulates. All of these methods have led to the practical release of avalanches but none appear to offer a universal solution to avalanche release in all circumstances. The gas exploder system is the most promising to date and is currently being
installed for operational use.
\end{abstract}

RÉsumé. Choix des méthodes pour le déclenchement artificiel des avalanches de neige. Une série de dispositifs ont été imaginés et essayés dans le but de produire le déclenchement d'avalanches de neige en perturbant ou en altérant mécaniquement le couvert neigeux. Il s'agit de techniques de substitution à l'utilisation classique de fortes charges d'explosifs et de projectiles d'artillerie. Des enceintes métalliques chargées d'un mélange explosif de gaz peuvent être mises à feu électriquement par contrôle à distance et rechargées pour une nouvelle mise à feu si besoin. Des sacs à air placés sous le neige peuvent être gonflés à des pressions relativement modérées pour rompre et déplacer le manteau neigeux. Des vibreurs à air comprimé peuvent mettre en mouvement un manteau neigeux instable quand les circonstance; sont favorables. Une membrane de polyéthylène placée à la surface du sol sur une pente forte empêche efficacement l'accumulation de la neige en permettant à la neige fraîche de glisser au fur et à mesure de la chute. Toutes ces méthodes ont conduit dans la pratique à des déclenchements d'avalanches, mais aucune ne semble offrir une solution universelle aux déclenchements dans toutes circonstances. Le système à explosion de gaz semble le plus prometteur actuellement et est fréquemment utilisé pour des installations opérationnelles.

Zusammenfassung. Verschiedene Methoden zur künstlichen Auslösung von Schneelawinen. Zur Auslösung von Schneelawinen durch mechanische Störung oder Veränderung der Schneedecke wurde eine Reihe von Geräten entwickelt und erprobt; sie sollen den bisher üblichen Gebrauch von Sprengstoff und Geschossen ersetzen. Kanister, gefüllt mit einem explosiven Gasgemisch, können elektrisch ferngezündet und - wenn nötig - nach einer Regenerierung erneut gezündet werden. Luftkissen, unter die Schneedecke gebracht, können unter angemessen niedrigem Druck aufgeblasen werden, um die Schneedecke zu spalten oder zu versetzen. Wirksame Vibratoren mit Druckluftantrieb können unstabilen Schnee unter günstigen Umständen versetzen. Eine Polyethylen-Membrane auf der Oberfläche eines steilen Berghanges verhindert wirkungsvoll die Ansammlung von Schnee, indem sie Neuschnee sofort nach dem Fallen zum Abrutschen bringt. Alle diese Methoden sind für die praktische Lawinenauslösung geeignet, aber keine stellt eine universelle Lösung unter allen möglichen Umständen dar. Zur Zeit lässt das Gasexplosionssystem am meisten erwarten; es
wird laufend zum Routinebetrieb installiert.

\section{INTRODUGTION}

The method of artificial avalanche release most widely used today is the initiation of snow-slab fracturing by high explosives. Such explosives, delivered to the avalanche release zone by hand or as artillery projectiles, provide a powerful disruptive force which can cause avalanche release in an unstable, stressed snow cover. Explosives have serious limitations for such applications, including safety and regulatory problems for handling and storage as well as limited availability of military weapons and ammunition. To provide alternatives to high explosives, a research program is now under way to design and field-test other methods of artificially releasing avalanches. Replacements for artillery and explosives are not expected to be found for all cases, but very possibly they can be developed for many of the smaller and more active avalanche paths which comprise a major part of the control activities. This paper summarizes the results from two winters of field tests (LaChapelle and others, 1975, $1976)$. 
Four different methods of releasing avalanches have been investigated. All have succeeded in some degree, none has yet been developed in a form that is universally applicable to all terrain and snow conditions. The four methods are: (I) substitution of a metered and rechargeable explosive mixture of gases for conventional high explosives, (2) inflation of buried air bags to disrupt and dislodge the superincumbent snow cover, (3) application of high-energy vibrations to dislodge unstable snow, and (4) modification of the snow-earth interface to enhance snow glide and frequent, minor avalanching.

Tests have been conducted at four different sites: Stevens Pass and Snoqualmie Pass in the Cascade Mountains of western Washington State, Red Mountain Pass in the San Juan Mountains of Colorado and in the Wasatch Mountains of Utah. The first two of these sites lie at an altitude range of $\mathrm{I} 200-\mathrm{I} 500 \mathrm{~m}$ in a maritime climate with heavy winter snowfalls occasionally interspersed with rain. The Colorado site is at an altitude range of $3400-3600 \mathrm{~m}$ in a cold, dry-snow climate with relatively light snowfall and intense radiation influences on snow metamorphism. The Utah site lies in an intermediate climate at an altitude of $3100 \mathrm{~m}$. All methods of release have been tested in both maritime and inland climates except interface modification, which to date has been tested only in Colorado.

\section{GAS EXPLODERS}

The use of high explosives to start avalanches under controlled circumstances is well established and empirical procedures and safety standards have been documented (Perla and Martinelli, 1976). A first step in seeking alternate methods of avalanche control has been to take advantage of the explosive release method while avoiding the problems of storing and handling conventional explosives. One way to avoid these problems is to use commercial two-part explosives which consist of two separate agents, solid or liquid, neither of which is an explosive in itself but which become active when mixed. An even simpler two-part explosive is a combustible mixture of gases, which can simultaneously simplify the problems of storage, mixing, delivery and firing. Such mixtures have lower detonation velocities and brisance than conventional high explosives, but do deliver considerable energy when detonated in practical quantity. Compensation for lower brisance can be found in the ease of delivering gases to and simultaneously firing multiple charges on a single avalanche path.

The gases chosen for these tests were oxygen and acetylene. These are widely available commercially in the welding industry and the technology of their storage, metering and mixing is well established. The available chemical energy from combustion (or explosive detonation) of oxygen and acetylene is equal to that of $5.3 \mathrm{~kg}$ of TNT for each cubic meter of an optimum gas mixture at atmospheric pressure.

A charging vessel is required to contain the mixed gases and then allow discharge of the explosive energy on detonation. To be practically useful, such a vessel must allow the chargefire cycle to be repeated indefinitely. The design of vessel chosen to meet these requirements is the steel canister shown in Figure I. The internal volume of this canister is $0.053 \mathrm{~m}^{3}$, yielding an optimum explosive energy equivalent to about $0.28 \mathrm{~kg}$ of TNT. A similar canister with lighter structure than that specified in Figure $\mathrm{I}$ was tested, but this was seriously deformed after several detonations and could not be considered durable. The illustrated canister design has been used in two separate multiple arrays during both test winters and has proven reliable. Some improvement in effectiveness the second winter was achieved by removing the flange around the lid and allowing the venting gases to eject laterally instead of being deflected downward. For operation, these canisters are installed in multiple arrays (three or four canisters per array) close to anticipated fracture-line positions in the release zone of avalanche paths. Where soil conditions permit, a hole is excavated and the canister buried so only the lid is left exposed. On bedrock they are anchored with heavy steel cables. In all cases they must be anchored securely against upward motion in the form of violent recoil on firing. 


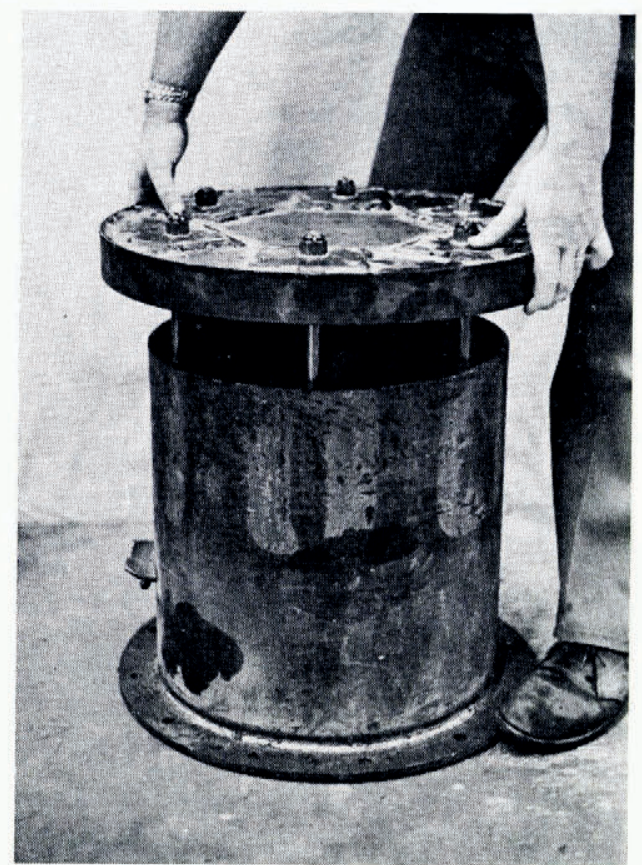

Fig. I. Steel canister used as a charging vessel for the gas exploder system. The lid is lifted on steel guide rods as shown to vent the exploding gases and is returned by heavy springs on the guide rods. Construction material is $\frac{1}{4}$ inch $(6.4 \mathrm{~mm})$ and $\frac{3}{16}$ inch $(9.6 \mathrm{~mm})$ mild steel.

These gas exploder canisters exert two effects on the overlying snow cover: the lid is thrust violently upward and the venting gases disrupt the surrounding snow. In snow up to about I $m$ deep, detonation produces visible effects at the snow surface, often in the form of a snow jet thrown into the air. In deeper snow there is no visible effect at the surface, as is usually the case with buried equivalent charges of conventional explosives.

The heart of the gas exploder system is the control unit (Fig. 2) which permits remote control of gas valving, mixing and ignition. Electrically controlled solenoid valves provide the key control function. The mixing chamber is the handle of a standard, commercial oxyacetylene welding torch, which contains needle valves for accurate control of gas flow and the critical feature of flashback suppression to keep flames from entering the gas feed lines. The mixed gases flow through an ignition chamber and into a distribution line to the individual canisters by way of needle valves which allow balancing of gas flow to each canister. Ignition is by electric spark, with the ignition flame propagating at high velocity down the distribution line to the canisters. This latter feature greatly simplifies the operation of multiple exploder arrays. Efficient recovery of explosive energy at the exploder unit is dependent on adequate distribution of the explosive gas mixture within the unit and on displacement of the air. Both are difficult to achieve. Introduction of the gas mixture through a manifold at several points within the unit is essential.

In addition to the canister design shown in Figure $\mathrm{I}$, two other exploder configuration have been tested. One is a steel pipe, o. $15 \mathrm{~m}$ internal diameter and $2.5 \mathrm{~m}$ long, with a series of holes in a line along the length of the pipe. Flaps of heavy rubber belting cover these holes. When the gas mixture is detonated inside the pipe it vents through the holes and past the flaps, providing an explosive impulse along an extended line. Tests to date show this to be an 
energetic exploder unit but without any particular advantage in effectiveness over the canisters. Another configuration makes use of a large truck tire bolted on one side to the rim of a wheel with the split rim removed from the opposite side where the other edge of the tire is free to be displaced. Explosion of a gas mixture within the tire is vented past the free edge and the accompanying elastic recoil imparts a powerful disruptive force to the snow cover. The tire exploder appears to be superior in effectiveness to the steel canister and will be tested operationally in the winter of $1976 / 77$.

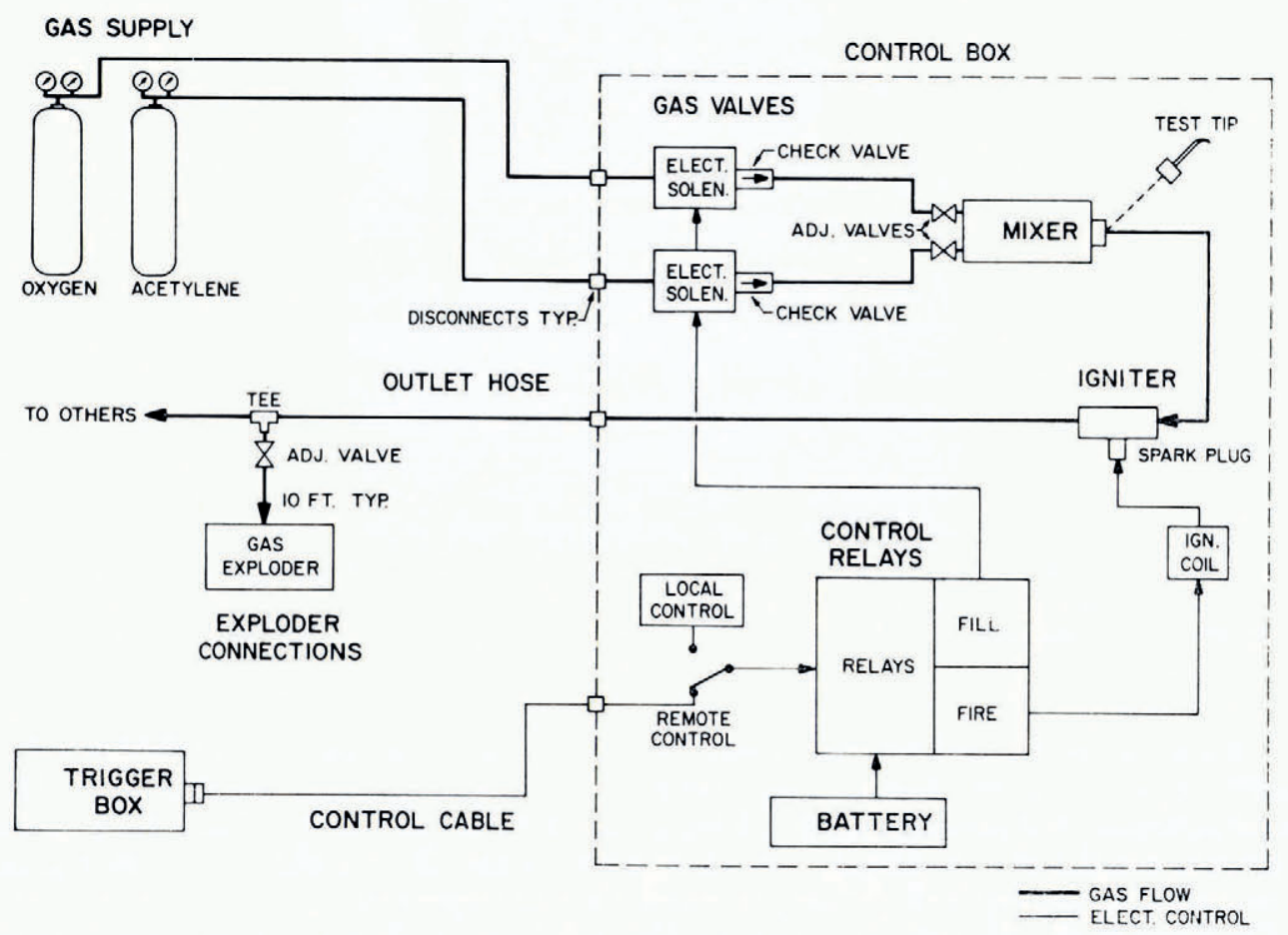

Fig. 2. Flow diagram for the gas-exploder control equipment. See text for further details.

An array of four gas exploder canisters has been tested for two winters at an avalanche path in the San Juan Mountains of Colorado where maximum snow cover depth typically is $\mathbf{I} . \mathbf{O}-\mathbf{I} .5 \mathrm{~m}$. Operational test firings have been made on sixteen occasions over these two winters, nine of them during unstable snow conditions when avalanches might be expected. Soft slab avalanches have been released on four of these nine occasions. The results compare favorably with several years of experience of avalanche release by artillery fire on this same path. A similar array has been tested at two different sites in the Cascade Mountains of Washington, one site each winter. No avalanche release was obtained from a total of twelve test firings under expected avalanche conditions. When buried under the deep, heavy snow cover of this maritime climate, the canisters do not appear to have enough explosive energy to cause surface disruption and avalanche release. This is not surprising, for comparable sizes of conventional explosive charges ( $0.28 \mathrm{~kg}$ TNT equivalent) when detonated at the bottom of a deep snow cover also produce little effect at the surface. Future tests in deep snow are planned using large tire exploders. 


\section{AIr BAGS}

Relatively small pressures $\left(c .0 .4 \mathrm{~kg} / \mathrm{cm}^{2}\right)$ are required to lift the snow of even a deep alpine snow cover, while larger but still modest pressures $\left(\mathrm{I}-2 \mathrm{~kg} / \mathrm{cm}^{2}\right)$ can break the rigid beam of even the strongest snow slab. The inflation using compressed air of sealed bags placed beneath the snow cover is a simple and efficient way to apply such pressures. Bags highly suitable for such an application are available commercially as cargo dunnage bags. These dunnage bags are large ( $1.3 \mathrm{~m} \times 2.8 \mathrm{~m}$ and $\mathrm{up}$ ), they are constructed of a nylon and neoprene shell with inner rubber bladder and are highly resistant to weathering and abrasion. A simple and reliable technology is thus available to apply breaking forces to a winter snow cover. As a method of avalanche control, the expected effect of inflating an air bag underneath a sloping snow cover is first to initiate surface cracking which may be propagated as a slab avalanche release, and further physically to displace a segment of the snow cover so that it may fall. Repeated inflation of a dense array of bags on a slope could also be expected to relieve stresses through repeated fracturing. Air bags are also effective in removing snow cornices through fracturing and displacement. An analogous application has already been introduced in Japan, where air bags are inflated in the bottom of open railway cars to empty them of snow collected during city street cleaning (personal communication from D. Kuroiwa).

Air bags have been tested for two winters in the applications discussed above. Their mechanical performance in breaking and lifting snow has been exactly as expected. The only failures occurred when two bags of a four-bag array were ruptured by the excessive pressure applied when they failed to inflate underneath $2 \mathrm{~m}$ of very dense and icy snow and when another bag at a different site ruptured for unknown reasons. In the first case new bags were deployed without previous inflation and compressed completely flat by the accumulating snow. This difficulty has not occurred with pre-inflated bags. The most severe test was the fracturing of glacial firn $2.2 \mathrm{~m}$ thick, density $580 \mathrm{~kg} / \mathrm{m}^{3}$, estimated Kinosita hardness $8 \mathrm{~kg} / \mathrm{cm}^{2}$. In this case surface cracks appeared when bag inflation pressure reached $2.0 \mathrm{~kg} / \mathrm{cm}^{2}$.

A fully inflated air bag (size $\mathrm{I} .3 \mathrm{~m} \times 2.8 \mathrm{~m}$ ) has a volume of $\mathrm{I} .2 \mathrm{~m}^{3}$ and a rated maximum inflation pressure of $1.05 \mathrm{~kg} / \mathrm{cm}^{2}$. Field inflation has been accomplished from compressed air bottles and from air compressors ranging widely in size, giving times to full inflation ranging from gos to $15 \mathrm{~min}$. The effects on the snow cover appear to be the same for all tested inflation rates. The bags have been inflated through pipes or hoses ranging from $\frac{3}{8}$ inch $(9.5 \mathrm{~mm})$ to $\mathrm{I}$ inch $(25.4 \mathrm{~mm})$ internal diameter and up to $200 \mathrm{~m}$ long. The larger size is necessary for fast inflation rates, especially at longer distances. Only a very small pressure differential exists to drive bag deflation, hence this is slow if the hose length is long. Internal hose diameter less than $\frac{1}{2}$ inch $(12.7 \mathrm{~mm})$ is not recommended, otherwise the deflation time becomes inconveniently long (several days).

An array of four air bags has been used for the frequent, successful removal of cornices near Red Mountain Pass, Colorado (Fig. 3). This cornice site overhangs an avalanche slope where the falling cornices have dislodged numerous avalanches, providing a two-fold benefit from the artificial release of cornices. Location of the bags is critical. Knowledge of local peculiarities of the cornice formation is essential to accurate bag location and this knowledge should be based on winter observations of snow conditions as well as summer examination of the terrain. The optimum bag location tends to shift during the winter as the depth of snow cover increases.

Arrays of one to four bags have been deployed in the release zones of small avalanche paths in both the Cascade Mountains of Washington and San Juan Mountains of Colorado as well as at one site in the Wasatch Mountains of Utah. The latter site used an automatic compressor installation adjacent to the avalanche path which was switched on by remote control using a coded radio signal. Mechanical performance of the air-bag systems at these sites has been satisfactory and snow-cover disruption vigorous but no direct slab releases by 


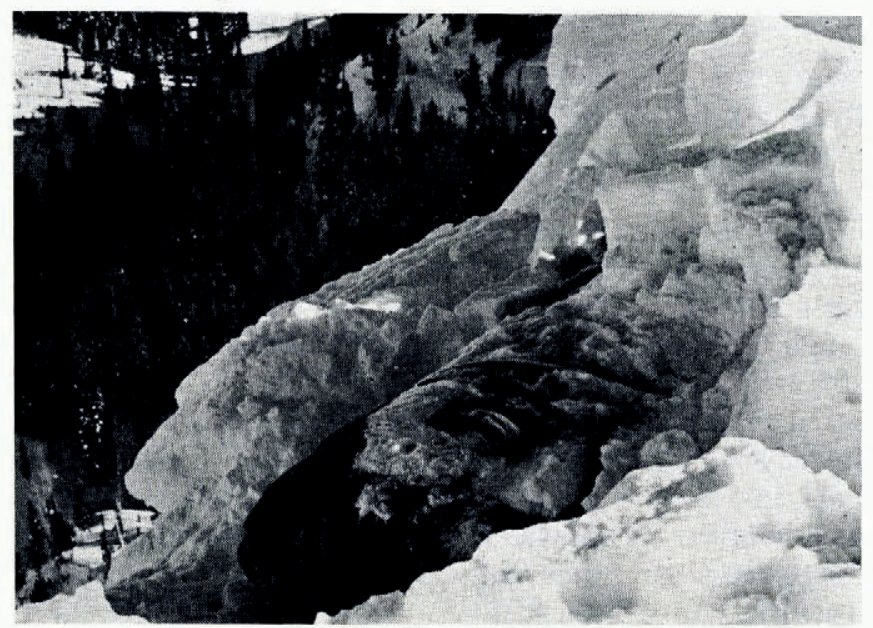

Fig. 3. An inflated air bag showing section of cornice removed during inflation. Red Mountain Pass, Colorado.

the initial snow fracturing have yet been achieved. In part this may be due to problems of inaccurate bag placement and a low frequency of avalanche conditions during $1975 / 76$, but the possibility exists that this mode of avalanche release may not be reliable. Slope installations of air bags have caused avalanches, but in a secondary fashion by dislodging snow blocks or loose snow sluffs on the surface which in turn triggered avalanche release below through dynamic loading. The effectiveness of air bags for this mode of avalanche control thus remains less clearly demonstrated than it is for cornice release.

\section{VIBRATORS}

Empirical field tests were started during the second year of the project to develop experience in the design and operation of high-energy vibrators and to find out whether in principle unstable snow can be induced to avalanche by mechanical vibration. Owing to the well-known ability of snow to absorb and dampen sounds and vibrations, there are legitimate questions about the efficacy of vibration for avalanche release. On the other hand, longstanding field experience with avalanches has shown that seriously unstable snow can be triggered into avalanching by very small signals, including, traditionally, the sound of a human voice. The results from a winter of field experiments are presented here.

Two test devices were constructed, both using compressed air for power. In brief, an oscillating platform driven by a large jackhammer was installed flush with the ground surface at the release zone of the Blue Point avalanche path near Red Mountain Pass, Colorado, and a portable metal grid driven by a commercial vibrator was used for tests on a highway cutbank near Stevens Pass, Washington.

The air flow to the jackhammer represents an input of 5-10 horsepower, while that for the commercial vibrator represents IO-15 horsepower. Because snow is soft and easily deformed, vibrating bodies initially deliver a large percentage of their output to compressing the adjacent snow, and then rapidly become decoupled from it by the air cavities developed. If the cavities are small, snow deformation from creep and settlement is slow to close them and subsequent tests begin in a decoupled state. Experience to date suggests that the grid style of vibrating unit quickly decouples from the snow and tends to build small, persistent cavities around the grid members. The platform surface parallel to the normal snow deposition appears to retain better contact, for settlement quickly brings the snow to rest on the platform and coupling is restored. Oscillation of the platform parallel to the snow cover also provides transmission of shear forces with minimum cavitation. 
The winter of $1975 / 76$ provided few opportunities for tests in highly unstable snow at both sites. Some tests were run with known stable snow when there was little expectation of avalanche release. One avalanche release with the platform vibrator was achieved at Red Mountain Pass on 2 February 1976. This was a small, soft slab avalanche running in a shallow snow pack on a depth-hoar layer near the ground. On two other occasions adjacent air bags released a cornice fall that triggered avalanches on this same slope after the vibrator had failed to do so. It appears that vibrators can in principle release avalanches under favorable conditions, but the tests so far have not been adequate to determine if vibrators can serve as a reliable release tool under a variety of snow conditions. It is doubtful that the present designs discussed here would be satisfactory.

\section{INTERFAGE MODIFICATION}

During the first winter of this project, experiments were conducted to see if plastic (polyethylene) sheets placed on the ground would encourage sluffing of snow on steep slopes and thus inhibit avalanche development. This was found to be the case with small areas $(2 \mathrm{~m} \times 3 \mathrm{~m})$ until the surrounding snow built to a depth sufficient to anchor the snow on the plastic and allow it to accumulate. Even after the plastic was covered, accelerated glide of the snow cover persisted throughout the winter.

These experiments were repeated the second winter, using larger sheets of plastic (polyethylene and reinforced polyethylene) placed in the release zones of small avalanche paths (Fig. 4). At two locations the plastic-covered areas of $8 \mathrm{~m} \times 3 \mathrm{r} \mathrm{m}$ were oriented with the long axis in the slope fall line. At the third location the plastic covered an area of $13 \mathrm{~m} \times 31 \mathrm{~m}$. Serious difficulties were experienced in anchoring these larger plastic sheets to the mountainside in the face of high winds. One test site eventually lost the plastic entirely, a second was damaged early in the winter, and only one survived intact until buried by the accumulating snow. But the same effects were found the second winter: snow simply will not adhere to this material on steep slopes until the surrounding snow gets deep enough to provide an anchor,

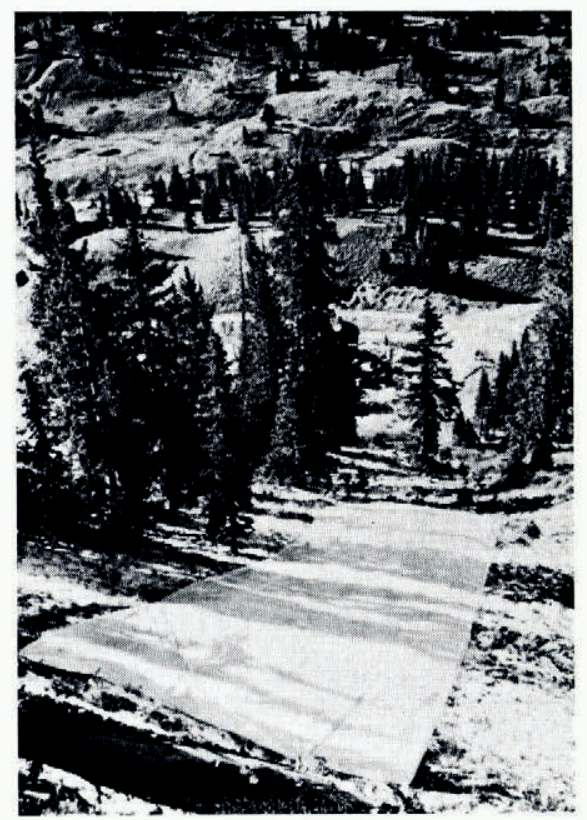

Fig. 4. Polyethylene sheet, $8 \mathrm{~m} \times 3^{\mathrm{I}} \mathrm{m}$, anchored to the ground in the release zone of a small avalanche path near Red Mountain Pass, Colorado. 
and in this case with larger sheets the required snow depth for anchoring was greater, $\mathrm{I}-2 \mathrm{~m}$. On the basis of evidence so far obtained in this cold, snowy climate, it appears that a sufficiently large area of mountainside covered with polyethylene sheet would remain snow-free most of the winter. The interface modification technique thus offers considerable promise as an avalanche control measure from the technical standpoint although there are some severe practical difficulties in the problem of anchoring the sheets, as well as of durability, and questions of labor costs if they are removed and re-installed each year or of aesthetic and ecological problems if they are left in place.

At present no evidence is available to assess the effects of this interface modification on a maritime snow cover. Tests in such a climate will begin in the winter of $1976 / 77$.

\section{Conclusions}

(I) An explosive mixture of gases can be reliably and repeatedly metered and fired under adverse winter conditions. The current design of exploders when buried under the snow cover as a multiple array in an avalanche release zone will consistently effect avalanche release in a high-altitude, continental snow climate where maximum depth does not exceed I-2 m. A more energetic exploder design, yet to be tested, is required for the deeper, heavier snow cover of a maritime environment.

(2) Inflating air bags under the snow cover is a simple and reliable procedure which is effective for removing cornices and inducing consequent avalanching by the cornice fall. To be consistently effective, a high density of bag deployment is required. Bag location is critical and must be determined by experience with each individual site. Air bag inflation also appears promising for direct release of avalanches on a slope by inducing slab fracture, but this latter application has not yet been confirmed by experiment. Evidence to date implies that the initial tensile fracture at the snow surface induced by inflating the buried bag does not initiate release of slab avalanches.

(3) Energetic vibrations applied to the snow cover can induce avalanche release under favorable circumstances in a shallow, unstable snow cover. Experiments to date have not identified a type of vibrator and mode of coupling which will reliably initiate avalanching.

(4) Modifying the snow-earth interface with polyethylene sheets in a cold climate is highly effective for inhibiting snow accumulation on slopes and enhancing glide of snow that does accumulate. In principle this may be the simplest and most reliable alternate method of avalanche control, but there are serious practical problems related to installing and maintaining plastic and to its ecological and aesthetic impact on the environment.

\section{Acknowledgement}

This research has been supported by Washington State Highway Department Research Agreement No. Y-r 637 with the University of Washington, Seattle, through cooperation with the Federal Highway Administration. The contents of this paper reflect the views of the author who is responsible for the facts and the accuracy of the data presented herein. The contents do not necessarily reflect the official views or policies of the Washington State Department of Highways or the Federal Highway Administration.

\section{REFERENCES}

LaChapelle, E. R., and others. 1975. Alternate methods of avalanche control, interim report 1974/75, by E. R. LaChapelle, G. B. Brown, R. J. Evans, J. B. Johnson, J. A. Langdon, M. B. Moore, P. L. Taylor. Washington State Highway Dept. Research Program Report i $9 . \mathrm{I}$.

LaChapelle, E. R., and others. 1976. Alternate methods of avalanche control, interim report 1975/76, by E. R. LaChapelle, J. B. Johnson, J. A. Langdon, C. R. Morig, E. M. Sackett, P. L. Taylor. Washington State Highway Dept. Research Program Report 19.2.

Peria, R. I., and Martinelli, M., jr. 1976. Avalanche handbook. U.S. Dept. of Agriculture. Forest Service. Agriculture Handbook 489 . 


\section{DISCUSSION}

R. L. BRown: What was the speed achieved by the covers of the gas exploders? In regard to placement of the exploders did you find an optimum position along the fall line of the slope?

E. R. LaChapelle: Cover speed has not been measured. The excursion time of the lid during firing is too fast to follow by eye. In answer to your second point this is still a matter for experiment. Basically we chose the locations on the basis of available avalanche release experience with conventional explosives.

T. LANG: Have you carried your work on the gas exploders far enough to have any cost estimates for installation in place of artillery in ski areas?

LAChapelle: The control unit might cost commercially $\$ \mathrm{I}$ ooo. The tyre-type exploders use discarded materials but require some labour. The main cost of installation is the labour, plus helicopter time for inaccessible sites.

W. St. LAwrence: Have you attempted to install your air bags in order to initiate cornice release instead of directly in the starting zone? Secondly, how do you select the days on which to fire your exploders?

LaChapelle: Yes. The air bags illustrated in my paper were located to effect avalanche release indirectly by cornice fall. Days are selected by some conventional forecasting technique used for normal artificial release with explosives. There is no special forecasting for these new tests.

M. Mellor: Two comments on surface modification. First, the thought that perhaps surface sheets and normal plastic membranes could be used to assess the relative significance of basal shear resistance and fracture-line tensile resistance in avalanche release. Second, for operational modification, perhaps "shotcrete" (as used in tunnel linings) could be applied to the surface, and ice-releasing paint (such as that used by CRREL at Sault Locks), applied to the smoothed concrete. The paint is dull-green, forming a suitable background for the painting of alpine flowers!

LAChapelle: I have considered the type of interface modification referred to in your second point and believe that it would be the most practical for a permanent installation.

G. L. Freer: What methods were used to anchor the plastic sheets?

LaChapelle: Steel rods were driven into the ground to serve as anchors for special attack:ments around the edges of the plastic sheets. 